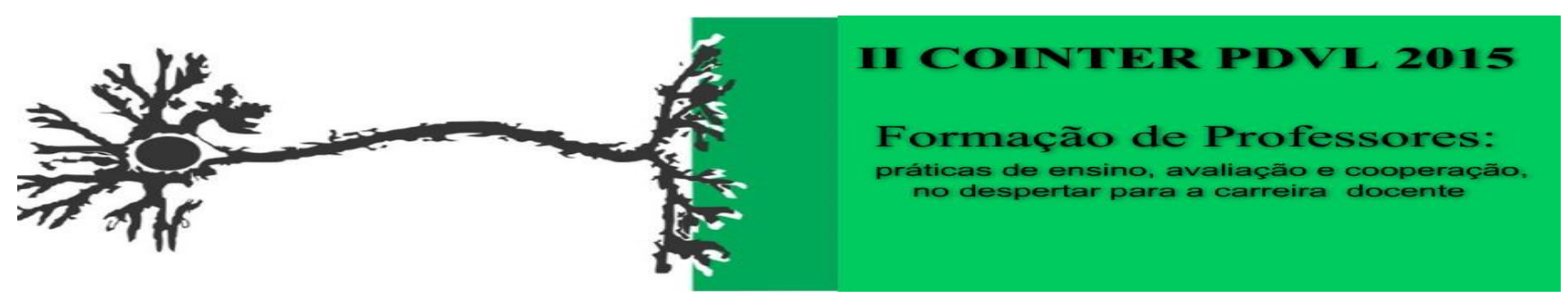

\title{
DESENVOLVENDO AÇÕES NO IFPB-CAMPUS JOÃO PESSOA PARA O INCENTIVO À LINCENCIATURA EM QUÍMICA
}

Apresentação: Relato de Experiência

\author{
Joedna Sabino de Souza ${ }^{1}$; Reynado Borges Galvão Serra ${ }^{2}$; Luana Reina Pinheiro Cunha ${ }^{3}$; \\ Jonildo Júnior da Silva Nogueira ${ }^{4}$
}

\section{Introdução}

Um dos grandes problemas enfrentados no contexto atual dentro das instituições de ensino superior - IES é a enorme evasão dos licenciandos, bem como a falta de estímulo e incentivo que os discentes do ensino básico não recebem para ingressarem nos cursos de licenciatura. Segundo Ruiz, Ramos e Hingel

a evasão dos estudantes nos cursos de Licenciatura, que as universidades brasileiras estão enfrentando ocorre por vários fatores. Dentre estes pode-se destacar a falta de investimentos em equipamentos e estrutura para os cursos, a falta de implantação de uma política que valorize o magistério, novas contratações de professores, índice de reprovação nas disciplinas que leva às sucessivas repetências, entre outros (2007, p. 11).

Tendo a educação um papel importante para a formação do indivíduo e com base em novas ferramentas para o desenvolvimento dentro da educação, foi essencial a elaboração de um projeto que atendesse a execução da tríade: pesquisa, ensino e extensão. Assim tornou-se importante a criação do Programa Despertado vocação na licenciatura- PDVL que tem como objetivo e pretensão, estimular para a da docência os alunos do ensino médio básico, que ainda estão adquirindo conhecimento para suas escolhas profissionais.

\section{Relato de Experiência}

Realizou-se uma proposta de ação vislumbrando atrair o olhar dos alunos do ensino médio do Instituto Federal de Educação, Ciência e Tecnologia- IFPB- Campus João Pessoa para conhecerem e participarem do Programa Despertando Vocações Para Licenciatura (PDVL). Parte da estudantada do $1^{\circ}$ e $2^{\circ}$ Ano do Ensino Técnico do turno da manhã, foi convidada a assistir um vídeo no auditório José Marques que abordava as ações do PDVL. Notadamente, foram

\footnotetext{
${ }^{1}$ Licenciatura em Química, IFPB Campus João Pessoa, eddnasouza@gmail.com

${ }^{2}$ Licenciatura em Química, IFPB Campus João Pessoa, reynaldoifpb@hotmail.com

${ }^{3}$ Licenciatura em Química, IFPB Campus João Pessoa, luanareine@hotmail.com

${ }^{4}$ Licenciatura em Química, IFPB Campus João Pessoa, jonildojunior96@hotmail.com
} 
apresentadas as ações do programa PDVL - Química visando o despertar para licenciatura daquele público alvo a partir das atividades que serão desenvolvidas em parceria com um grupo de licenciandos em Química do IFPB - campus João Pessoa. Entre os aspectos positivos que este curso de Licenciatura em Química detém destaca-se o conceito cinco, avaliado pela Coordenação de Aperfeiçoamento de Pessoal de Nível Superior (CAPES), disponibilidade de bolsas para estudantes que participam de projetos submetidos e aprovados em editais. Durante a exibição do vídeo os discentes receberam formulários, cujo objetivo foi saber o quantitativo de interessados em conhecer as ações do programa.

\section{Considerações}

Dentro dos cursos de licenciatura, é de suma importância analisar o crescimento do docente quando assume sua participação dentro do PDVL - Química, visto que ele estará na luta por uma valorização e melhoria da educação brasileira a partir do magistério. Tal ação teve um aspecto positivo, o Gráfico 1, traz o quantitativo de interessados no programa. Podemos denotar que os interessados são poucos, todavia, para a primeira ação já se pode pensar como um trabalho vantajoso. Tais ações devem ser continuadas e ocorrerão ao longo dos anos vindouros, pois só assim a educação e o incentivo a formação do professor terão seus avanços.

Gráfico 1. Quantitativo interessados ou não em participar do PDVL

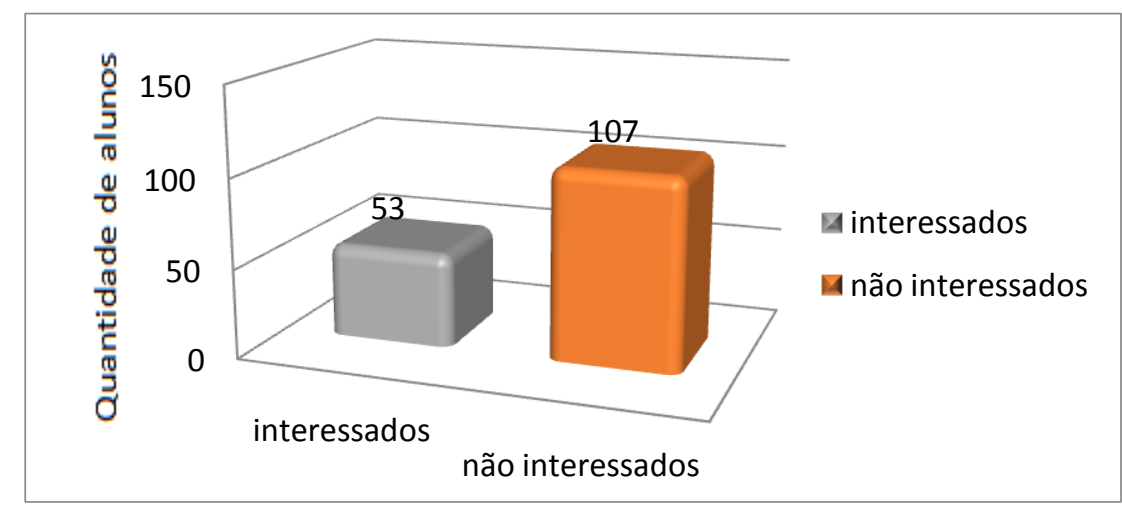

\section{Referências}

RUIZ, A.I.; RAMOS, M.N. e HINGEL, M. Escassez de professores no ensino médio: propostas estruturais e emergenciais. Brasília: Ministério da Educação; Conselho Nacional de Educação; Câmara de Educação Básica, 2007. Disponível em: http://portal.mec.gov. br/cne/arquivos/pdf/escassez1.pdf. Acessado em: 03 nov. 2015.

HOFFMAN, J. Avaliação mediadora: uma prática em construção da pré-escola à universidade. Porto Alegre: Mediação, 2001. 